p-ISSN. 2086-9029

e-ISSN. 2654-5675

Vol. 22 No. 1, Hlm. 1-158, Juni 2020

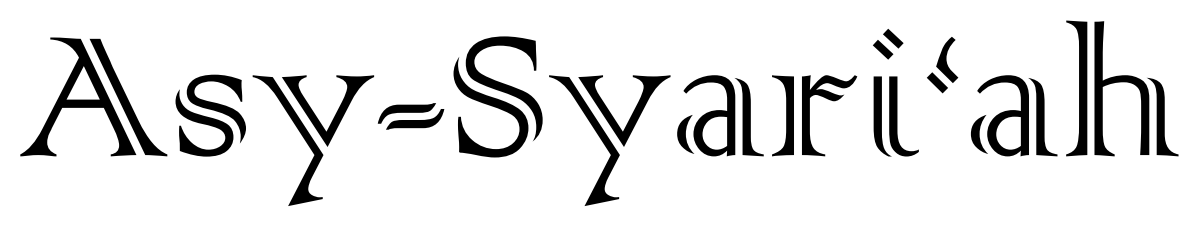

- Hukum Waris Islam Sebagai Instrumen Kepemilikan Harta

$(1-20)$ Hafidz Taqiyyudin

- Komparasi Metodologi Hukum Aliran Maqasidi dan Aliran Syakli

$(21-34)$ Hudzaifah Achmad Qotadah

- Reinterpretasi Hak Ijbar dalam Hukum Perkawinan Islam di Keluarga $(35-50)$ Pesantren

Kudrat Abdillah

- Dimensi Kondisionalitas dan Fleksibilitas Al-Quran bagi Implementasi $(51-66)$ Fatwa DSN-MUI tentang Produk Bank Syariah

Ahmad Hasan Ridwan, Asep Rahmat

- Validitas Hadis Tidak Ada Kisas bagi Orang Tua yang Membunuh Anaknya

Moh. Ahsanuddin Jauhari, Enceng Arif Faizal, Syahrul Anwar, Atep Mastur, Deden Najmudin

- Penguatan Resolusi Konflik Berbasis Tradisi Sunnah Nabi

Alamsyah

- Sistem Perencanaan, Pelaksanaan dan Pengawasan Industri Halal di Wilayah Provinsi Banten

Akhyakudin, Suja'i, Muhammad Abduh

- Reformulation of Family Legal in Indonesia for Female Maslahah

Wahidullah, Murniati, Yushinta Eka Farida, Jumaiyah

- The Concept and Aplication of Covenant in Financing Gold Pawn By Sharia Bank in West Java

Neni Nuraeni, Dewi Sulastri, Zulbaidah

- Tinjauan Sosiologi Hukum tentang Kepatuhan Masyarakat terhadap ( $147-158)$ Undang-Undang Wakaf

Deden Effendi

FACULTY OF SHARIA AND LAW

STATE ISLAMIC UNIVERSITY SUNAN GUNUNG DJATI BANDUNG-INDONESIA IN COLLABORATION WITH ASOSIASI SARJANA SYARIAH INDONESIA 


\section{Asy-Syari'ah}

Volume 22, Number 1, 2020

\section{EDITOR-IN-CHIEF}

Ine Fauzia

\section{EDITORIAL BOARD}

Sofyan al-Hakim, UIN Sunan Gunung Djati Bandung, Indonesia Deni Kamaludin Yusup, UIN Sunan Gunung Djati Bandung, Indonesia Meria Utama, Fakultas Hukum Univrsitas Sriwijaya, Indonesia Dewi Mayaningsih, UIN Sunan Gunung Djati Bandung, Indonesia Andrey Sujatmiko, Fakultas Hukum Universitas Trisakti, Jakarta, Indonesia Hetty Hassanah, Universitas Komputer Indonesia, Indonesia

\section{PEER-REVIEWERS}

Muhammad Irfan Helmy, IAIN Salatiga, Semarang, Indonesia Ahmad Ali Nurdin, UIN Sunan Gunung Djati Bandung Tajul Arifin, UIN Sunan Gunun Djati Bandung, Indonesia Mohamad Anton Athoillah, UIN Sunan Gunung Djati Bandung, Indonesia Mrs. Renny Supriyatni, Universitas Padjadjaran, Indonesia Ahmad Tholabi Karlie, UIN Syarif Hidayatullah Jakarta, Indonesia Ija Suntana, UIN Sunan Gunung Djati Bandung, Indonesia Zezen Zaenal Mutaqin, University of California, Los Angeles, United States Ahmad Fathonih, UIN Sunan Gunung Djati Bandung, Indonesia Rahman Syamsuddin, Universitas Islam Negeri Alauddin Makassar, Indonesia

\section{PROOFREADER/DESIGN COVER}

Nanang Sungkawa

\section{LAYOUT EDITOR}

Opik Rozikin

Asy-Syari' ah has been accredited based on the determination of Director General of Research and Development Strengthening, Ministry of Research, Technology and Higher Education of Republic of Indonesia, No. 14/E/KPT/2019 (valid until 2023). 


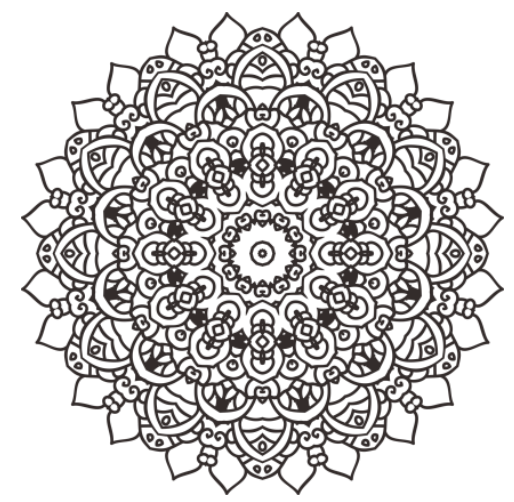

\title{
PENGUATAN RESOLUSI KONFLIK BERBASIS TRADISI SUNNAH NABI
}

\author{
Alamsyah \\ Fakultas Syari'ah Universitas Islam Negeri Raden Intan Lampung \\ Jl. Endro Suratmin Kec. Sukarame, Kota Bandar Lampung, Lampung, 35131 \\ E-mail : alamsyah@radenintan.ac.id
}

\begin{abstract}
This paper examines the theological foundation of conflict resolution from the treasury of the Prophet's Sunnah. This foundation is important to be studied as an epistemology and argument for strengthening conflict resolution in the reconstruction of Islamic science in the modern era. The Sunnah of the Prophet as one of the important sources of Islamic teachings after the Qur'an will strengthen the theological foundation of conflict resolution. This study uses the document study method, with data sources from hadith texts and classical literature to then be processed and analyzed qualitatively using a historical approach. Research findings show that the Sunnah of the Prophet has exemplified the basis and model of conflict resolution or conflict resolution, such as conflict resolution in laying the Hajar Aswad stone, the Medina charter and the Hudaibiyah agreement. The Sunnah of the Prophet as written in the hadith texts is an important source in extracting and determining conflict resolution in society. The Sunnah of the Prophet brings living values in society and is followed by its members. Because Islam is a religion that is embraced by the majority of Indonesian people, the conflict resolution based on the Sunnah of the Prophet provides a better direction. The Sunnah of the Prophet teaches that the model of conflict resolution depends on the type of conflict and the situation and condition of the people who are experiencing conflict. Conflict resolution in the traditions of the Sunnah of the Prophet has developed into the reality of society called local wisdom. Therefore, local wisdom is actually a development of the teachings of the Sunnah of the Prophet who has experienced actualization. The important thing to do is to contextualize and reactivate the values of wisdom in the Sunnah of the Prophet into a model of conflict resolution to remain relevant in the midst of current developments. The various values of conflict resolution or reconciliation in the Sunnah of the Prophet are relevant as approaches to conflict resolution in order to create a harmonious family and a united and peaceful Indonesian state.
\end{abstract}

Keywords: local wisdom, mediation, conflict resolution, the sunnah of the prophet 
Abstrak: Tulisan ini mengkaji tentang landasan teologis resolusi konflik dari khazanah Sunnah Nabi. Landasan ini penting dikaji sebagai epistemologi dan argumentasi penguatan resolusi konflik dalam rekonstruksi ilmu keislaman di era moderen. Sunnah Nabi sebagai salah satu sumber penting ajaran Islam setelah al-Qur'an akan memperkuat landasan teologis resolusi konflik. Penelitian ini menggunakan metode studi dokumen, dengan sumber data dari teks-teks hadis dan literatur klasik untuk kemudian diolah dan dianalisis secara kualitatif dengan menggunakan pendekatan historis. Temuan penelitian menunjukkan bahwa dalam Sunnah Nabi telah banyak dicontohkan dasar dan model penyelesaian konflik atau resolusi konflik, seperti penyelesaian konflik dalam peletakkan batu Hajar Aswad, piagam Madinah dan perjanjian Hudaibiyah. Sunnah Nabi sebagaimana tertulis dalam teks-teks hadis adalah satu sumber penting dalam penggalian dan penentuan resolusi konflik dalam masyarakat. Sunnah Nabi membawa nilai-nilai yang hidup dalam masyarakat dan diikuti oleh anggotanya. Oleh karena Islam merupakan agama yang dipeluk oleh mayoritas masyarakat Indonesia, maka resolusi konflik berbasis Sunnah Nabi memberikan arah lebih baik. Sunnah Nabi mengajarkan bahwa model penyelesaian konflik tergantung kepada jenis konflik serta situasi dan kondisi masyarakat yang mengalami konflik. Resolusi konflik dalam tradisi Sunnah Nabi telah berkembang ke dalam realitas masyarakat yang disebut dengan kearifan lokal. Oleh karena itu maka kearifan lokal sebenarnya merupakan pengembangan dari ajaran Sunnah Nabi yang telah mengalami aktualisasi. Hal yang penting dilakukan adalah melakukan kontekstualisasi dan reaktualisasi nilai-nilai kearifan dalam Sunnah Nabi ke dalam model reolusi konflik agar tetap relevan di tengah perkembangan kekinian. Berbagai nilai-nilai resolusi konflik atau islah dalam Sunnah Nabi tersebut relevan sebagai pendekatan dalam penyelesaian konflik agar terwujud keluarga yang harmoni dan negara Indonesia yang bersatu dan damai.

Kata Kunci: kearifan lokal, mediasi, resolusi konflik, sunnah nabi. 


\section{Pendahuluan}

Konflik selalu mengiringi kehidupan manusia selama masih ada kepentingan, kehendak, dan cita-cita yang ingin diwujudkan. Berbagai hambatan dan halangan serta benturan kepentingan selalu muncul, dan ketika hal itu ingin dihilangkan maka konflik antar manusia akan muncul. Benturan-benturan kepentingan antara individu dengan individu, antara individu dengan kelompok, atau kelompok dengan kelompok, tidak menutup kemungkinan selalu akan terjadi. Jika hal ini terjadi, maka konflik merupakan sesuatu yang pasti terjadi dalam masyarakat.

Beragam konflik yang sering muncul dalam berbagai kejadian bukan terjadi begitu saja, akan tetapi merupakan akumulasi dari ketimpangan-ketimpangan hak dan kewajiban yang banyak tidak terpenuhi dengan baik. Demikian juga adanya perbedaan nilai, status, kekuasaan, kelangkaan sumber daya, serta distribusi yang tidak merata, yang dapat menimbulkan ketimpangan dalam masyarakat. Dengan demikian konflik dalam kehidupan manusia tidak mungkin dapat dihilangkan sampai tuntas. Konflik akan selalu dijumpai dalam kehidupan manusia sebab akan selalu muncul perbedaan dan pertentangan kepentingan atau antara hak dan kewajiban ketika harus dipenuhi kebutuhan hidup. Ketika kepentingan saling berbenturan serta hak dan kewajiban tidak terlaksana dengan baik, maka kemungkinan terjadinya konflik sulit terhindarkan.

Konflik sering dianggap sebagai sesuatu yang negatif, merugikan dan mengganggu kestabilan. Sebenarnya konflik itu merupakan hal yang normal dan tidak dapat dielakkan karena masyarakat dan konflik merupakan satu kesatuan yang tidak terpisahkan dan bersifat alamiah. Konflik terjadi karena ada dua pihak yang terlibat, ada tujuan yang dijadikan sasaran, ada tindakan dan ada situasi yang melahirkan sebuah pertentangan. Dengan kata lain, konflik mempunyai sisi lain yang berdaya positif yaitu sebagai sebuah proses menuju perubahan, sehingga konflik harus diakui keberadaannya, diolah, dimanajemen, dan diubah menjadi kekuatan untuk menuju perubahan yang baik.

Berbagai pendekatan yang dapat dilakukan untuk penyelesaian konflik, misalnya model penyelesaian berdasarkan posisi kepentingan dan kebutuhan sumber konflik, model boulding, model intervensi pihak ketiga dan banyak model yang lainnya. Model dan metode penyelesaian konflik dipilih secara tepat sesuai dengan sebab-sebab konflik dan kondisi masyarakat yang mengalaminya. Dalam masyarakat Indonesia sejak lama sudah berjalan penyelesaian konflik secara damai berdasarkan nilai-nilai yang hidup dalam budaya kearifan setempat (kearifan lokal). Nilai-nilai kearifan lokal ini penting dikaji kembali perannya dalam penyelesaian konflik keluarga.

Berbagai kajian tentang resolusi konflik dan yang terkait dengan Islam telah banyak dilakukan, namun masih jarang atau tidak ada yang digali atau didasarkan kepada tradisi Sunnah Nabi sebagaimana termuat dalam literatur hadis. Beberapa penelitian tentang resolusi konflik yang terkait dengan tulisan ini antara lain diuraikan berikut ini. 
Supriyanto Pasir menulis artikel dengan judul "Pendidikan Resolusi Konflik Berbasis Al-Qur'an". Tulisan ini menguraikan tentang konsep resolusi konflik dan bentukbentuknya, terutama yang terdapat dalam al-Qur'an. Penulis menemukan setidaknya ada 12 cara untuk membangun resolusi konflik yang dapat digunakan dalam Al-Qur'an, di antaranya adalah saling memaafkan dan melupakan, membangun komunikasi yang bijak, berbuat sesuatu yang baik dan menimbulkan penghargaan, saling memahami dan mengerti, membuka jaringan keomunikasi, membuang prasangka buruk, dan tidak diskriminatif atau membeda-bedakan kedudukan orang lain. ${ }^{1}$

Penelitian lain ditulis oleh Muhammad Harjuna dengan judul 'Islam dan Resolusi Konflik". ${ }^{2}$ Dalam tulisan ini Harjuna menjelaskan tentang esensi Islam sebagai agama yang mengajarkan perdamaian dan melarang konflik, di mulai dengan anjuran mengucapkan salam, melarang permusuhan, penghinaan dan adu domba, mewajibkan persamaan, rekonsiliasi dan keadilan. Tulisan ini belum mengkaji secara khusus ajaran perdamaian dan resolusi konflik dari perspektif Sunnah Nabi atau hadis.

Kajian berikutnya dilakukan oleh Muadil Faizin dengan judul "Piagam Madinah dan Resolusi Konflik di Indonesia". ${ }^{3}$ Tulisan ini membahas tentang kemunculan Piagam Madinah pada awal Nabi Muhammad hijrah ke Madinah lalu membuat kesepakatan dengan berbagai kelompok di sana. Kesepakatan yang berisi perjanjian perdamaian dan sanksi bagi pelanggarnya ini kemudian dikenal sebagai Piagam Madinah atau Sahifah al Madinah. Penulis menyimpulkan bahwa Piagam Madinah sangatrelevan dalam upaya membangun perdamaian di Indonesia yang plural ini. Namun tulisan ini tidak membahas secara khusus resolusi konflik dari tradisi kenabian Muhammad saw.

Akram Abdul Cader telah menulis tentang resolusi konflik dengan judul "Islamic Principles of Conflict Management; A Model of Human Resource Management", dalam International Journal of Cross Culture pada Nopember 2017. ${ }^{4}$ Artikel ini menggali dan menganalisis tentang prinsip-prinsip ajaran Islam dalam manajemen konflik. Modelmodel manajemen dalam menyelesaikan konflik juga digali, baik dari sumebr tekstual atau pengalaman hidup. Maka prinsip-prinsip verifikasi, pelayanan, nasehat,saling membantu, kerjasama, sabar dan persaudaraan juga dijelaskan. Dengan demikian artikel ini tidak mengkaji secara khusus tentang resolusi konflik dalam Sunnah Nabi.

Artikel lain yang terkait ditulis oleh Mohammad Tahlil Azim, dengan judul artikel Religiosity and Conflict Handling Styles: A Study of a Muslim Community, dalam

\footnotetext{
${ }^{1}$ Supriyanto Pasir, Pendidikan Resolusi Konflik Berbasis al-Qur'an, dimuat dalam jurna, baik dari all Nadwa, Junal Pendidikan Islam dalam Vol. 7, Nomor 2, Oktober 2013

${ }^{2}$ Muhammad Harjuna, Resolusi Konflik dalam Islam, jurnal Religi, Vol. XIV, No. 1, Jan-Juni 2018, hlm.. $23-43$

${ }^{3}$ Dimuat dalam Jurnal Nizham, vol V, no. 01, edisi Januari - Juni 2017.

${ }^{4}$ Akram Abdul Cader, Islamic Principles of Conflict Management; A Model of Human Resource Managemen, dalam jurnal bernama International Journal of Cross Culture pada Nopember 2017, hlm. 1- 9.
} 
International Journal of Islamic Thought. ${ }^{5}$ Azim menulis tentang pandangan Islam dalam menyelesaikan konflik khususnya yang terjadi dalam masyarakat di Arab Saudi. Penelitian kuantitatif ini menegaskan bahwa Islam sangat menekankan perdamaian dan selalu mendorong konflik diselesaikan secara damai. Dalam masyarakat muslim pun juga banyak dipraktekkan tradisi penyelesaian konflik secara damai. Dengan demikian penelitian ini tidak sama dengan substansi artikel yang penulis lakukan.

\section{Resolusi Konflik dan Relasinya dengan Agama}

Resolusi Konflik adalah suatu proses untuk mendapatkan jalan keluar dari sebuah konflik. Dalam berbagai literatur tentang resolusi konflik, ditemukan banyak model yang dapat ditempuh dalam penyelesaian konflik, di antaranya:

Pertama, Intervensi pihak ketiga, model ini yaitu melalui arbitrase maupun mediasi. Arbitrase adalah resolusi konflik dengan cara menjadikan pihak ketiga untuk menyelesaikan masalah yang terjadi, dan keputusan pihak ketiga harus diterima dan ditaati oleh masing-masing pihak. Sedangkan mediasi berarti pihak ketiga hanya berfungsi untuk menjembatani penyelesaian konflik yang terjadi dalam masyarakat. ${ }^{6}$ Kedua, Dengan menawarkan metode penyelesaian konflik melalui teknik menghindar, menaklukkan, dan mengakhiri konflik sesuai prosedur. Ini namanya Model Boulding. Ketiga, Konflik diselesaikan berdasarkan sumber. Dalam model ini, seorang juru damai harus mengetahui lebih dahulu sumber-sumber konflik: baik relasi, nilai, pandangan, dan lain-lain. Setelah sumbernya diketahui, maka dapat dilakukan langkah untuk menyelesaikan konflik. Setiap sumber masalah tentunya memiliki solusi masing-masing sehingga cara penyelesaian konflik tidak hanya satu. Keempat, Cara assimilasi atau model pluralisme budaya, ini dapat membantu untuk dilakukan resolusi konflik. Sebagai misal, individu atau kelompok didorong melakukan reaksi tertentu terhadap pengaruh lingkungan sosial dengan mengadopsi kebudayaan yang baru masuk. Faktor lainnya selain hal-hal di atas adalah persoalan akomodasi, di mana dua kelompok atau lebih yang berkonflik harus sepakat untuk menerima perbedaan budaya, yang harus dinyatakan melalui penyamaan kepentingan bersama. ${ }^{7}$

Resolusi konflik memiliki hubungan erat dengan agama. Hal ini disebabkan karena agama bisa memiliki dua wajah. Satu sisi agama sebaga agen resolusi yang mendorong perdamaian, dan di sisi lain agama juga bisa muncul sebagai sumberpecahan dan permusuhan yang harus didamaikan. Sebagai agen perdamaian, maka ajaran berbagai agama mengajak umatnya untuk hidup damai, saling menghormati, menghargai perbedaan, tidak menyakiti dan tidak mendiskriminasi. Sebagai sumber potensi konflik,

\footnotetext{
${ }^{5}$ Mohammad Tahlil Azim, Religiosity and Conflict Handling Styles: A Study of a Muslim Community, dalam International Journal of Islamic Thought, Vol. 12: (Dec.) 2017.

${ }^{6}$ Ibid

${ }^{7}$ Soerjono Soekanto, Sosiologi Suatu Pengantar (Jakarta: PT. Raja Grafindo Persada.,2006)
} 
agama memang juga menurunkan ajaran yang spesifik, lokal, situasional dan kondisional, sehingga implementasinya bisa relevan pada satu waktu dan tempat tetapi juga bisa tidak relevan atau berefek negatif pada waktu atau tempat lainnya. Inilah yang melatarbelakangi ajaran agama harus selalu dikontekstualisasi dan direinterpretasi, termasuk dalam model dan teknis resolusi konflik ini.

Dalam konflik hukum, yang sering terjadi di antara manusia atau badan hukum, pada garis besarnya ada dua cara penyelesaian, yaitu: Pertama, melalui putusan hukum legal formal yang dibuat oleh hakim pengadilan yang dinamakan penyelesaian secara litigasi. Kedua, melalui perdamaian (islâh, rekonsiliasi, resolusi konflik, mediasi konflik, dsb) baik melalui putusan hakim di lembaga peradilan maupun putusan lembaga mediasi moderen seperti Badan Arbitrasi Nasional atau melalui mediasi secara budaya kekeluargaan tradisional. Penyelesaian model kedua ini dinamakan non litigasi. Dalam ajaran Islam juga ditemukan beberapa cara penyelesaian konflik sebagaimana yang diterangkan dalam beberapa ayat al-Qur'ân dan Hadîs Nabi.

\section{Macam dan Sebab Terjadi Konflik}

Sebagian pakar mendefinisikan bahwa konflik (conflict) atau yang sering disamakan dengan sengketa (dispute), ${ }_{1}^{8}$ adalah sebuah perselisihan antara dua pihak yang dapat menganggu hasil kerja, baik produktifitas atau efesiensi. Sebagai contoh, konflik keluarga atau konflik dalam keluarga adalah perselisihan antara dua pihak atau lebih yang menganggu kegiatan sehari-hari dalam berbagai aspek kehidupan keluarga, mulai dari persiapan, proses dan berakhirnya kehidupan keluarga. Konflik memiliki dampak beragam mulai skala kecil sampai dengan bahaya besar.

Bentuk konflik bermacam-macam, mulia dari konflik antarindividu, konflik antaretnik, konflik antaragama dan internal agama, konflik antargolongan atau kelas sosial, konflik antarras, konflik antarnegara atau negara dan rakyat. ${ }^{9}$ Konflik yang terjadi dalam keluarga dapat digolongkan ke dalam konflik antarindividu.

Dilihat dari wilayah persoalannya, konflik memiliki beberapa macam bentuk lagi. Konflik keluarga misalnya dapat dirinci lagi menjadi beberapa macam konflik, yaitu konflik praperkawinan, seperti konflik dalam pemilihan dan penetapan jodoh, penentuan mahar, uang jujur, proses pembayaran, pembatalan lamaran, pembatalan perjanjian perkawinan, dan lain-lain. Ada lagi konflik dalam masa perkawinan (syiqâq), seperti masalah pemberian nafkah lahiriah dan nafkah batin, perselingkuhan, pengasuhan anak,

\footnotetext{
${ }^{8}$ Ada perbedaan pendapat di kalangan ilmuan tentang makna konflik dan sengketa. Sebagian sarjana mengatakan kedua istilah tersebut memiliki makna sama dan tidak ada perbedaan mendasar. Namun sebagian ilmuan lainnya mengatakan dua istilah tersebut memiliki perbedaan, baik makna maupun luas cakupan dan tempat penggunaannya. Lihat Takdir Rahmadi, Mediasi; Penyelesaian Sengketa Melalui Pendekatan Mufakat (Jakarta: PT Raja Grafindo, 2010) hlm. 1-4

${ }^{9}$ Soerjono Soekanto, Sosiologi Suatu Pengantar (Jakarta: Rajawali Press, 1990), hlm.. 239.
} 
pergaulan dalam rumah tangga dan hubungan seksual, dan perkawinan monogami atau poligami, dan sebagainya. Demikian juga ada konflik dalam perceraian (talâq dan gugat) berupa masa persiapan atau pisah ranjang, pihak yang mengambil inisiatif memulai cerai, biaya dan proses cerai, dan hubungan keluarga pasca perceraian.

Dalam pembagian harta bersama (gono gini) dan harta waris (tirkah) bisa terjadi konflik berupa perebutan haarta bersama, penetapan jumlah dan macam harta bersama, penetapan jumlah harta waris, penetapan bentuk harta yang jadi barang waris, penetapan para ahli waris, dan jumlah bagian masing-masing ahli waris. Demikian juga pada pengasuhan dan nafkah anak (hadânah) misalnya muncul konflik penetapan siapa yang berhak mengasuh, bagaimana biaya pengasuhan, proses lama pengasuhan, serta hak masing-masing bapak dan ibu. Dalam soal harta warisan, konflik bisa terjadi mulai dari penentuan siapa saja yang berhak menjadi pewaris, status harta warisan, jenis, macam dan jumlahnya, jumlah bagian untuk masing-masing pewaris, dan tempat penyelesaian sengketa warisan.

Dalam persoalan waqaf, banyak terjadi konflik tentang status barang wakaf, jumlah dan volume wakaf, sengketa kepemilikan barang wakaf, model pengelolaan wakaf, dan penggunaan hasil wakaf, baik saat pewakaf (wakif) masih hidup atau sudah meninggal dunia. Ada juga konflik hibah dan wasiat, dll, yang terkait dengan kehidupan keluarga.

Konflik secara umum disebabkan oleh beberapa faktor. Faktor pertama, karena perbedaan nilai. Nilai adalah sesuatu yang menjadi dasar, pedoman, tempat setiap manusia menggantungkan pikiran, perasaan, dan tindakan. Konflik yang disebabkan oleh perbedaan nilai ini merupakan konflik yang bersumber pada perbedaan rasa percaya, keyakinan, bahkan ideologi atas apa yang menjadi keyakinan. Kedua, karena kurang komunikasi. Banyak konflik terjadi hanya karena dua pihak yang saling bersengketa tidak atau kurang berkomunikasi. Komunikasi yang gagal antara dua pihak menyebabkan tidak akan dapat menyampaikan pikiran dan tindakan sehingga membuka perbedaan informasi di antara mereka, dan hal semacam ini dapat mengakibatkan terjadinya konflik. Ketiga, kurang efektifnya kepemimpinan. Kepemimpinan yang baik secara politis adalah kepemimpinan yang kuat, demokratis dan adil. Namun untuk mendapatkan pemimpin yang memenuhi kriteria demikian merupakan hal yang cukup sulit. Konflik akibat kepemimpinan yang tidak efektif ini banyak terjadi pada suatu komunitas yang pemimpinnya memiliki karakter kurang efektif juga, kurang tegas atau kurang jelas.

Faktor keempat, akibat ketidakcocokan dalam peran. Pemahaman yang berbeda tentang peran dan peran yang dimainkan tidak cocok juga dapat menyebabkan terjadinya konflik. Hal ini disebabkan ada pihak yang mempersepsikan peran mungkin berbeda dari persepsi pihak lain tentang peran tersebut. Faktor kelima, akibat produktivitas yang rendah. Konflik dapat pula muncul akibat kedua belah pihak seringkali 
kurang atau tidak mendapatkan keuntungan dari hubungan mereka sehingga muncul saling duga buruk di antara mereka. Faktor penyebab keenam adalah perubahan Keseimbangan. Adanya perubahan keseimbangan dalam suatu masyarakat dapat menyebabkan konflik, baik karena faktor alam atau faktor sosial. ${ }^{10}$

\section{Perdamaian dalam al-Qur'an}

Islam adalah agama yang bersifat terbuka dan dinamis. Prinsip ajaran Islam memang terbentuk dari wahyu-wahyu ketuhanan, namun kebanyakan ajaran Islam justru bersumber dan diinspirasi oleh keberadaan dan perkembangan budaya umat manusia. Berbagai aturan dalam wilayah rumah tangga sampai kepada ekonomi dan kenegaraan bersumber dari tradisi masyarakat. Wahyu yang turun membawa ajaran dari Allah swt tidak datang ke dalam ruang dan tempat yang kosong dari peradaban, tetapi selalu bertemu dengan kehidupan manusia yang telah mencapai taraf perkembangan tertentu. Dengan demikian Islam sangat menghargai dan memperhatikan budaya, tradisi, dan hukum masyarakat lokal. Ajaran Islam yang berasal dari wahyu dan yang turun selalu memperhatikan sistem budaya yang hidup di tengah masyarakat. Dalam perkembangannya, antarmasyarakat dapat terjadi dialog, asimilasi atau bahkan adhessi persenyawaan antara wahyu dan budaya masyarakat, dalam hal ini adalah budaya masyarakat Arab pralslam.

Kitab suci al-Qur'an menegaskan bahwa Muhammad saw diturunkan ke dunia adalah untuk membawa rahmat kasih sayang bagi alam semesta, bukan untuk alim, bukan sebaliknya atau nilai-nilai yang telah hidup dalam masyarakat yang ada, baik nilainilai itu berasal dari agama sebelumnya atau murni hasil budaya setempat. Islam justru datang untuk memperkuat (muayyid-musaddiq) ajaran para nabi sebelumnya, serta mengembangkan nilai-nilai kemanusiaan universal dan lokal. Maka banyak tradisi masyarakat Arab pra Islam (jâhiliyyah) ajaran Hanifiyyah dari nabi Ibrâhim as, ajaran Yahudi dari Nabi Mûsa as, dan ajaran Nasrani dari Nabi Isa as yang masih diteruskan oleh Nabi Muhammad saw. Demikian pula masih banyak ketentuan Syari'at Islam sebenarnya berasal dari tradisi masyarakat Arab pra Islam yang diadopsi menjadi Syari'at, seperti tahkîm, syûra, âqilah (denda), qisâs, diyat, sistem perwalian ${ }^{11}$. Perwalian ini memiliki banyak bidang, baik dalam persoalan kesukuan, sistem perkawinan, kekeluargaan, sampai pada pengurusan anak dan harta. Sedangkan hukuman rajam dan salib diambil dari tradisi hukum Yahudi. Artinya ajaran Islam memang berasal atau diadopsi dari berbagai agama.

\footnotetext{
${ }^{10}$ Agus Sriyanto, Penyelesaian Konflik Berbasis Budaya Lokal, dalam jurnal Ibda', (Purwokerto: P3M STAIN Purwokerto), Vol. 5, No. 2, Jul-Des 2007, hlm. 286-301

${ }^{11}$ Khalīl Abdul Karīm, al-Juzūrut Tārikhiyah lis Syarīah Islāmiyah, terjemah oleh Kamran As'ad (Yogyakarta: PT LKiS, 2010) hlm. 5
} 
Prinsip hidup positif masyarakat Arab lama juga terus dikembangkan oleh Rasulullah SAW, seperti prinsip jujur (siddiq), pantang berdusta, berani, satria, tidak munafiq, menghormati tamu, teguh dengan janji, kesetiakawanan tinggi. Sedangkan praktik lama yang buruk yang dipraktikkan oleh sebagian kabilah, seperti mengubur anak perempuan hidup-hidup, oleh beliau dilarang untuk dilakukan lagi. Artinya bahwa masyarakat Arab pralslam telah memiliki nilai-nilai positif dalam bermasyarakat dan bahkan ada beberapa orang di antara mereka yang memang mempraktikkan nilai-nilai kemuliaan tersebut. Oleh karena itu, maka Rasulullah SAW mengatakan "khairukum fil jâhiliyyah khairukum fil Islâm" yang artinya bahwa sebaik-baik orang pada masa jahiliyyah adalah juga sebaik-baik orang pada masa Islam.

Dalam rangka menegaskan hubungan yang positif antara Islam dan tradisi kearifan lokal ini, maka ulama menyusun kaidah fikih yang menyatakan bahwa "adat istiadat dapat dijadikan hukum" (al-'âdah muhakkamah). Dengan kaidah ini maka tidak relevan lagi untuk mempertentangkan Islam dan budaya lokal karena memang ajaran Islam juga banyak yang terbentuk dari adat istiadat. Implikasi selanjutnya maka lahir kaidah fikih bahwa "hukum dapat berubah dengan perubahan waktu, tempat, keadaan dan adat istiadat" (tagayyurul ahkâm bitaghayyuril azminah wal amkinah wal ahwâl wal 'awâid). ${ }^{12}$

Beberapa ayat al-Qur'an yang mengajak untuk menyelesaikan sengketa dan perselisihan adalah Surat Al-Hujurat ayat ke-10 menyatakan "Sesungguhnya orangorang yang beriman adalah bersaudara, karena itu damaikanlah antara kedua saudaramu (yang berselisih) dan bertakwalah kepada Allah agar kamu mendapat rahmat". Dalam Surat an Nisa' ayat 114 dinyatakan "Tidak ada kebaikan pada kebanyakan obrolan mereka, kecuali dari orang yang menyuruh untuk memberikan sedekah, atau berbuat kebaikan, atau mengadakan perbaikan hubungan di antara manusia. Dan, barangsiapa yang berbuat demikian karena mencari keridaan Allah, maka kelak Kami memberinya ganjaran yang besar".

Al-Qur'ân dalam beberapa ayat menyiratkan bahwa penyelesaian konflik atau sengketa dapat dilakukan dengan dua cara di atas, yaitu melalui putusan hakim pengadilan (hukum) dan dapat pula melalui jalur perdamaian (islâh). Akan tetapi alQur'ân sangat menganjurkan perdamaian sebagai pilihan utama dalam penyelesaian konflik. Sebagai contoh, jika terjadi sengketa suami istri (syiqâq) maka diajarkan agar masing-masing pihak yang bersengketa untuk mengutus juru runding atau hakam yang fungsinya untuk menyelesaikan sengketa. Putusan hakam ini dapat untuk mendamaikan kedua pihak yang berkonflik atau bersifat memutuskan. ${ }^{13}$

\footnotetext{
${ }^{12}$ Ibn al-Qayyim al-Jauziyyah, I'lām al-Muwaqqi'in 'an Rabb al-'Alamīn (Beirut: Dār al-Fikr, 1995) vol. II,
} hlm. 2

\footnotetext{
${ }^{13}$ Q.S. an-Nisa' ayat 35
} 
Demikian pula jika terjadi nusyûz (penyimpangan) oleh pihak suami maka dibolehkan melakukan islâh (perdamaian) antara suami dan istri untuk saling berbagi hak dan kewajiban. ${ }^{14}$ Dalam kasus jika suami istri tetap saling menuduh zina tanpa mau didamaikan, maka cerai secara li'ân adalah jalan terakhir. Allah swt juga menyatakan bahwa jika ada dua golongan umat Islam berperang maka wajib didamaikan (islâh), jika ada kelompok yang tidak mau berdamai maka barulah kelompok itu diperangi. ${ }^{15}$

Al-Qur'an juga mengajarkan agar dikirim orang-orang yang bisa menyelesaikan persengketaan, dan ini sebagai upaya perdamaian, misalnya dalam pertengkaran antara suami dan istri, atau yang disebut syiqaq. Dalam upaya penyelesaian ini maka al-Quran menegaskan untuk menghadirkan pihak ketiga, "Dan jika kamu khawatir terjadi persengketaan antara keduanya, maka kirimlah seorang juru damai (hakam) dari keluarga laki-laki dan seorang juru damai dari keluarga perempuan. Jika keduanya (juru damai itu) bermaksud mengadakan perbaikkan, niscaya Allah memberikan taufik kepada suami-istri itu. Sungguh Allah Maha Mengetahui, Maha Teliti. ${ }^{16}$

Juru damai ini akan melakukan mediasi terhadap pihak-pihak yang berkonflik. Mediasi dalam resolusi konflik mengharuskan perubahan dari semua pihak yang terlibat. Perubahan tidak boleh berupa pemaksaan karena itu bukan solusi yang diharapkan, tapi sekadar menyesuaikan diri terhadap tekanan besar dari kekuatan yang lebih besar. Perubahan yang dipaksakan memang bisa membuka kesempatan bagi berlangsungnya bentuk pertemuan secara cepat yang dituntut dalam resolusi. Pemaksaan jika dilakukan maka hasilnya tidak efektif, karena setelah itu dihentikan maka kebiasaan lama yang negatif akan kembali seperti semula dengan segala bentuk pola atau model destruktif yang semakin besar. ${ }^{17}$

\section{Resolusi Konflik dan Mediasi Perdamaian dalam Sunnah Nabi}

Sunnah Nabi juag mengajarkan tentang perdamaian dan ajakan menjadi mediator konflik dalam menyelesaikan sengketa. Berikut dikutip ucapan dan tindakan Rasulullah saw dalam garis perdamaian tersebut.

Hadis Nabi saw tentang perdamaian.

Sabda Nabi saw dalam sebuah teks hadis menyatakan,

"Perdamaian dengan sesama muslimin itu diperbolehkan kecuali perdamaian yang menghalalkan suatu yang haram atau mengharamkan suatu yang halal. Dan kaum

\footnotetext{
${ }^{14}$ Q.S. an-Nisa': 128

${ }^{15}$ O.S. al-Hujurat : 9

${ }^{16}$ Q.S. An-Nisaa ayat 35 .

${ }^{17}$ Sebagaimana dikutip oleh Ahmad Rifa'i dari Ronal. S. Kraybill., dalam artikel Konflik dan Resolusinya dalam Perspektif Islam, jurnal Millah, edisi khusus Desember 2010, hlm. 184.
} 
Muslimin harus memenuhi syarat-syarat yang telah mereka sepakati kecuali syarat yang mengharamkan suatu yang halal atau menghalalkan suatu yang haram" ${ }^{18}$

Sabda Nabi saw tentang muslim agar memberi rasa aman.

Beliau berkata: "muslim sebenarnya adalah muslim yang memberikan keselamatan bagi orang lain dari gangguan lisan dan tangannya". ${ }^{19}$

Fakta sejarah penyelesaian konflik Hajar Aswad.

Praktik kearifan lokal sebagai basis resolusi konflik telah dipraktekkan dalam sejarah peradaban Islam Arab, misalnya tradisi penyelesaian sengketa secara damai telah dilakukan dan menjadi kebiasaan yang berlangsung terus menerus secara lama. Aswad yang hanyut akibat banjir.

Sebelum diangkat menjadi seorang Rasul, Muhammad SAW sudah dipercaya oleh masyarakat Mekah saat itu sebagai orang paling dipercaya, sehingga beliau diberi gelar dengan Muhammad al-Amin (Muhammad yang Dipercaya). Pada suatu ketika terjadi banjir besar di kota Mekah sehingga menyebabkan banyak bangunan hanyut atau bergeser posisinya dari tenpat semula, termasuk Hajar Aswad, sebuah batu yang sangat dihormati oleh kaum Qurasiy Mekah. Oleh karena Hajar Aswad diyakini sebagai batu istimewa maka semua pihak, baik suku, sub suku, pimpinan, dan sebagainya, berebut untuk mengangkatnya dan mengklaim sebagai orang berhak untuk mengembalikan batu tersebut ke tempat semula di samping Ka'bah. Berbagai kabilah bahkan bertekad agar bisa meletakkan Hajar Aswad pada tempatnya, bahkan salah satu kabilah yakni Bani Abdid Dar telah bersumpah dengan mencelupkan tangan mereka pada satu wadah yang dipenuhi darah sebagai bukti keseriusan mereka untuk bisa mengangkat batu tersebut. Dalam sejarah ini kemudian hari dikenal La'aqotu ad-Dam (sesendok darah). Ketika sengketa perebutan itu mentok dan tidak ada jalan keluar lalu mereka sepakat mempercayakan kepada orang paling dipercaya, yaitu Muhammad saw, untuk mengangkat dan memindahkannya. Hal yang luar biasa adalah beliau tidak mau mengangkat dan memindahkan batu tersebut sendirian. Dengan bijaksana beliau meletakkan Hajar Aswad di atas sorbannya lalu mengajak kepada para pemimpin suku yang bersengketa untukbersama-sama mengangkat batu itu ke tempat semula. Setelah sampai di tempat yang dituju maka barulah beliau sendiri yang mengangkat dan meletakkan batu tersebut di tempat semua. ${ }^{20}$

${ }^{18}$ Hadis di atas diriwayatkan oleh Bukhâri 4/451, oleh Imam Ahmad 2/366, Abu Dâwud no. 3594, Ibnu Jârud no. 637, al Hâkim 2/45, Ibnu 'Adiy no. 2088 dari Abu Hurairah ra. Dalam software al-Bayan Mausu'at alHadis al-Nabawi al-Syarif nomor hadis 1663 . Ini juga dimuat dalam https://almanhaj.or.id.

${ }^{19}$ Hadis riwayat Bukhari dengan hadis no 10, Muslim dengan nomor 4, juga diriwayatkan oleh Tirmizi, Nasai. Abu Dawud dan Ibnu Majah.

${ }^{20}$ Muhammad Said Ramadhan al-Buthi, Sirah Nabawiyah, terjemahan (Jakarta: Penerbit Rabbani Press, 2003) hlm. 159 dan 210. 
Membangun Aliansi Perdamaian dalam Piagam Madinah

Piagam atau perjanjian Madinah dibuat saat Muhammad SAW baru saja hijrah (pindah) ke Madinah. Konflik yang mudah terjadi dalam masyarakat Madinah yang heterogen menuntut munculnya seorang kuat yang dapat menguasai sebagian atau seluruh wilayah Madinah agar dapat teratur dan dikendalikan. Ketika Nabi SAW tiba di Madinah, beliau tampaknya memahami benar bahwa masyarakat vang dihadapi adalah masyarakat yang majemuk yang masing-masing golongan menyimpan sikap permusuhan terhadap golongan lain. Untuk itu beliau melihat perlunya dillakukan langkah-langkah strategis untuk menata, dan mengatur hubungan antarberbagai golongan serta pengaturan berbagai aspek kehidupan. Langkah tersebut adalah membangun aliansi perdamaian melalui sebuah kesepakatan yang dalam sejarah dinamakan sebagai Piagam Madinah (Sahîfah al-Madînah).

Banyak kalangan sejarawan menempatkan Piagam Madinah ini sebagai konstitusi umat manusia pertama dalam sejarah. ${ }^{21}$ Ibn Hisyâm dalam karya monumentalnya berjudul al-Sîrah al-Nabawiyah menuliskan panjang lebar isi Piagam Madinah ini. ${ }^{22}$ Piagam Madinah merupakan perjanjian perdamaian yang mengikat di antara berbagai komunitas yang ada di kota Madinah dan sekitarnya. Kelompok besar yang mengikatkan diri dalam piagam perjanjian ini adalah kelompok Arab muslim dari suku Aus dan Khazraj dan kelompok Yahudi yang terdiri dari beberapa suku. Perjanjian ini juga memuat ketentuan-ketentuan ikatan perdamaian dan hukuman bagi yang melanggarnya, Jika dikaji secara jernih tentang isi perjanjian tersebut jelas muatannya merupakan ketentuan hukum tidak tertulis yang memang sudah ada dalam tradisi masyarakat Arab, namun Piagam Madinah mempertegasnya dalam bentuk perjanjian secara tertulis.

Ada tiga kelompok masyarakat yang disebutkan secara tegas dalam dokumen piagam tersebut. Kelompok pertama, kelompok muslim yang terdiri dari golongan Muhajirin dan Anshar. Mereka ini terdiri dari bani Auf, Saidat, Haris, Jusyam, al-Najjar, Amr ibn Auf, al-Nabit, dan al-Aus. Suku-suku ini dikelompokkan sebagai kaum alKhazraj, sedangkan nomor 6 - 8 digolongkan sebagai kaum al-Aus. Masing-masing bani tersebut masih terbagi lagi ke dalam beberapa sub suku atau divisi yang daiam Piagam Madinah disebut thaifat. Kelompok kedua, kelompok Yahudi yang terdiri dari bani Auf, al-Najjar, a]-Haris, Saidat, Jusyam, al-Aus, Tsa'labat, Jafnat dan Syaibat serta kelompok orang-orang yang dekat dengan mereka yang dalam piagam disebut dengan bithanat. Mengenai nama-nama suku Yahudi yang sama atau menggunakan nama-nama suku Arab ialah untuk mengidentifikasikan diri mereka sebagaimana klan Arab karena memang mereka tinggal di lingkungan orang Arab Madinah. Pendapat lain karena memang berbagai suku Yahudi itu telah bercampur dengan orang-orang Arab sehingga

\footnotetext{
${ }^{21}$ William M. Watt, Muhammad at Madina (Oxford: Oxford University Press, 1956) hlm. 221-225

${ }^{22}$ Ibn Hisyām, al-Sìrah al-Nabawiyah (Kairo: al-Bābi wa al-Halabi, vol. I, h. 150. Lihat juga Ibn Ishāk, Sïrah al-Rasūl (Beirut: Dār al-Fikr, 1970) hlm. 72
} 
tidak memiliki afilinitas atau kesukuan yang jelas lagi serta telah terpisah dari organisasi kesukuan induknya yang besar. Oleh karena itu nama-nama mereka disebut seperti nama-nama suku Arab. Jjka berbagai suku Yahudi yang telah disebutkan banyak berasimilasi dengan suku-suku Arab maka berbeda dengan tiga suku utama Yahudi lainnya yajtu Qainuqa, Nadhir dan Quraizhat. Ketiga suku ini sangat memusuhi Nabi dan karena merasa superior lalu mangkhianati perjanjian sehingga akhirya mereka terusir dan terhapus namanya dari teks piagam tersebut. Kelompok ketiga, kelompok-kelompok Arab musyrik yang turut mengikat perjanjian dengan Nabi Saw. ${ }^{23}$

Ketiga kelompok besar di atas saling bersaing, memendam konflik bahkan saling menjatuhkan dan berperang. Kedatangan Muhammad saw di Madinah adalah menjadi mediasi perdamaian sehingga bisa dikonsolidasikan dalam sebuah kekuatan besar. Sema diikat dalam kesepakatan yang ditulis dalam sebuah penrjanjian, yang disebut Perjanjian atau Piagam Madinah.

Menurut Suyuthi Pulungan, Piagam Madinah memuat empat belas prinsip yaitu prinsip umat. prinsip persatuan dan persaudaraan, prinsip persamaan, prinsip kebebasan, prinsip hubungan antar satu pemeluk dengan lainnya, prinsip tolong menolong dan membela orang yang teraniaya, prinsip hidup bertetangga, prinsip Perdamaian, prinsip pertahanan, prinsip musyawarah, prinsip keadilan, dan prinsip pelaksanaan hukum. ${ }^{24}$

Gencatan senjata dalam perjanjian Hudaibiyah

Ini dilakukan Beliau dalam rangka strategi perdamaian dan untuk kemenangan dakwah Islam dalam jangka panjang. Perjanjian Hudaibiyah adalah suatu perjanjian yang dibuat di Hudaibiyah, satu desa kecil di bagian utara Mekkah pada Februari 628 M. Di antara satu tradisi yang sangat dihormati di kalangan Arab adalah larangan membawa senj ata untuk berperang di bulan-bulan haram, termasuk di antaranya bulan Zulka'dah. Pada bulan inilah Rasulullah bersama rombongannya yang berjumlah 1400 orang mengadakan perjalanan dari Madinah untuk menunaikan ibadah umrah di Mekah. Jadi tujuan kedatangan rombongan Rasulullah ke Mekkah adalah untuk ibadah, bukan untuk berperang atau merusak aturan yang berlaku.

Menjelang tiba di kota Mekah, rombongan Nabi ditahan oleh utusan Quraisy di suatu tempat bernama Hudaibiyah dan tidak boleh melanjutkan perjalanan ke Mekah. Setelah dilakukan negosiasi maka disepakati beberapa perjanjian, di antaranya disepakati bahwa kaum muslimin saat itu harus kembali ke Madinah dan tidak diperkenan-

${ }^{23}$ Alamsyah, Otentisitas Piagam Madinah dalam Perspektif Ilmu Hadis (Bandung: Penerbit Pustaka, 2008), hlm. 78

24 Suyuthi Pulungan, Prinsip-Prinsip Piagam Madinah dalam Tata Pemerintahan (Jakarta: Penerbit Rajawali, 1994), hlm. 121. Hasan Ibrahim Hasan menyebut Piagam Madinah memuat empat ajaran yang substansinya sama dengan Pulungan. Lihat: Hasan Ibrahim Hasan, Tarikh al-Islam, (Kairo : Maktabah al-Nahdhah, 1979), hlm. 116 
kan untuk melakukan ibadah umrah tahun itu. Mereka diperbolehkan datang tahun depan dengan ketentuan hanya tiga hari dan tidak diperkenankan membawa senjata.

Dalam hadîs Sahl bin Hunaif ra dinyatakan bahwa Rasulûllah saw membuat perjanjian Hudaibiyah dengan orang Quraisy Mekah walau banyak yang menentangnya, seperti Umar ibn al-Kahttâb, namun ternyata Perjanjian Hudaibiyah ini yang mengantarkan kemenangan umat Islam pada masa selanjutnya. ${ }^{25}$ Menurut al-Barrâ' bin Azib r.a, adalah Ali bin Abû Tâlib yang menulis isi naskah perdamaian antara Nabi s.a.w dengan orang-orang Musyrikîn pada hari perjanjian Hudaibiyah. Nabi pernah melarang agar jangan ditulis kalimah "Muhammad utusan Allâh" dalam draft perjanjian itu. Karena Ali tidak mau menghapus kalimat itu, maka Nabi saw lalu menghapusnya sendiri. ${ }^{26}$

Selain itu, dalam perjanjian itu disepakati jika seorang laki-laki dari Makkah datang ke Madinah tanpa izin dari tuannya, dia harus dikembalikan ke Makkah. Sebaliknya jika ada orang dari Madinah yang datng ke Makkah, maka tidak akan dikembalikan ke Madinah. Perjanjian ini berlaku selama selama 10 tahun. Awalnya perjanjian ini dianggap merugikan umat Islam, namun pada akhirnya justru berpihak kepada kemenangan. Dalam perjanjian inilah kita mendapatkan Rasulullah menampakkan dirinya bukan saja sebagai nabi tapi juga sebagai diplomat dan negosiator ulung dengan visi jauh ke depan. ${ }^{27}$ Dengan sikap bijaksana ini Nabi Muhammad saw telah memberi contoh teladan dalam membuat perdamaian atau memberi solusi terhadap konflik di antara berbagai suku atau pihak yang bersengketa.

\section{Relevansi Sunnah Nabi tentang Perdamaian dengan Kearifan Lokal Nusantara}

Data hadis yang memuat Sunnah Nabi dan fakta sejarah di atas menunjukkan bahwa Sunnah Nabi sangat menekankan perdamaian dan agar dilakukan mediasi konflik dengan berbagai cara dan media, termasuk melalui kearifan Lokal. Penyelesaian konflik seharusnya memang disesuaikan dengan latar, konteks atau setting tempat konflik itu terjadi. Jadi pendekatan umum sebenarnya tidak relevan diterapkan dalam menangani masalah konflik lokal sehingga dibutuhkan model khusus. Kearifan lokal (local wisdom) merupakan pendekatan dalam penyelesaian konflik yang belum banyak dikaji tetapi sebenarnya telah lama berjalan.

Kearifan lokal yang sudah ada sejak dahulu dan masih hidup sampai sekarang seperti "Alon-alon Asal Kelakon" di Jawa Tengah atau Yogyakarta, ajaran "Basusun Sirih" di kalangan Melayu Sumatra, juga adat "Badamai dan Baakuran" yang populer dalam masyarakat Banjar di Kalimantan atau di daerah lainnya, Dalihan Natolu" di kalangan

\footnotetext{
${ }^{25}$ lbid, nomor hadis 1057 .

${ }^{26}$ lbid, nomor 1056

${ }^{27}$ Fitrah Amaliyah, Perjanjian Hudaibiyah Bukti Diplomasi Rasulullah, dimuat dalam http://www.kompasiana.com, pada 22 Oktober 2019 pukul 20.05 WIB.
} 
suku Tapanuli, ada juga ajaran "Rumah Betang" bagi suku Dayak di Kalimantan Tengah, "Menyama Braya dalam masyarakat pulau Bali, "Saling Jot dan Saling Pelarangan di masyarakat Sasak NusaTenggara Barat, atau "Siro Yo Ingsun, Ingsun Yo Siro" di Jawa Timur dan tradisi "Tepung Tawar" dalam masyarakat Musi Rawas Sumatera Selatan. Berbagai tradisi dan kearifan lokal seperti ini yang masih ada serta berlaku di masyarakat, berpotensi untuk dapat mendorong keinginan hidup rukun dan damai. Hal itu karena kearifan tradisi lokal pada dasarnya mengajarkan perdamaian dengan sesamanya, lingkungan, dan Tuhan. ${ }^{28}$

Berbagai nilai-nilai kebijaksanaan masyrakat lokal di atas sangat sejalan dengan nilainilai Sunnah Nabi yang mengajarkan perdamaian dan musyawarah dalam menyelesaikan masalah atau konflik. Perdamaian sebagai solusi konflik akan berdampak lama dan lebih menentramkan. Penyelesaian secara kekeluargaan tersebut dilakukan dengan melibatkan aspek rasional, emosi dan perasaan maka penyelesaian bersifat tuntas dan dapat diterima semua pihak yang bertikai. Di sinilah resolusi konflik akan menawarkan kebersamaan atau sama-sama menguntungkan (Win-win Solution) bagi yang bersengketa dan tidak merugikan satu pihak sementara pihak lain diuntungkan (Win Lose Solution).

Dengan demikian nilai kearifan dalam masyarakat Nusantara, baik yang muslim maupun non muslim, sebenarnya sudah sejalan dengan Islam. Berbagai nilai-nilai tersebut ada yang bersumber dari wahyu tertulis, atau lahir dalam bentuk lain yang sebenarnya juga hasil pengembangan ajaran wahyu dan lalu hidup dalam masyarakat. Kearifan lokal tersebut bisa pula berasal dari tradisi masyarakat Nusantara sebelum Islam datang, namun kemudian mengalami inkulturasi dan asimilasi, sehingga hasilnya semakin mengkristal menjadi nilainilai perdamaian dan keharmonisan.

Dengan demikian tidak ada pertentangan antara Islam atau Sunnah Nabi dengan kearifan lokal dan keduanya tidak perlu dibenturkan. Bermacam-macam tradisi muslim Nusantara tersebut memuat nilai positif sehingga dapat dijadikan media menyelesaikan sengketa, seperti ajaran "pela gandong" di kalangan masyarakat Maluku, ajaran "setungku tiga batu" dalam masyarakat Papua yang menopang keharmonisan antara penganut muslim, Nasrani dan Animisme.

Demikian juga tradisi "Adat Badamai-Baakuran" untuk menciptakan perdamaian jika terjadi perselisihan dalam masyarakat Banjar baik yang di Propinsi Kalimantan Selatan, maupun di Riau dan Jambi. Mereka lebih terhormat memilih cara kekeluargaan dalam penyelesaian sengketa, menjaga tatanan harmoni dan tidak melanggar kearifan tradisional. ${ }^{29}$

\footnotetext{
${ }^{28}$ Agus Sriyanto, hlm. 286-301

${ }^{29}$ Ahmadi Hasan, Adat Badamai dalam Budaya Masyarakat Banjar (Banjarmasin: IAIN Antasari Press, 2009) hlm. 99-101
} 
Masyarakat Minangkabau Sumatera Barat juga mengenal lembaga "Kerapatan Kaum, Suku dan Anak Nagari', demikian juga di Aceh ada fungsionaris "Keuchik, Tuha Peut Gampong, dan Imeum Meunasah" yang dapat mendamaikan perselisihan keluarga, bahkan bisa memutus jika tidak bisa didamaikan. ${ }^{30}$

Dalam masyarakat Lampung dikenal dan masih hidup nilai budaya "pi'il pesenggiri" dan "Muwakhi" yang maknanya sangat Islami. Budaya "pi'il pesenggiri" memuat ajaran menjaga kehormatan diri dan nilai etika, ${ }^{31}$ sedangkan "muakhi" mengajak hidup bersaudara, dalam berbagai ikatan, sehingga dapat menjadi pemersatu dan perekat keharmoniasan. $^{32}$

Dengan demikian nilai-nilai bijaksana dalam berbagai tradisi Lokal Nusantara di atas sangat Islami dan sejalan dengan prinsip Sunnah Nabi dalam perdamaian, serta tepat dalam mediasi karena menekankan kepada keharmonisan, kebersamaan, demokrasi, saling berbagi, toleransi, dan menghormati sehingga dapat membangun keluarga harmonis dan bahagia, serta memperkuat kebhinekaan sebagai syarat mutlah tegaknya Negara Kesatuan Republik Indonesia (NKRI) secara harmoni.

\section{Simpulan}

Perdamaian adalah dambaan semua umat manusia, apapun agama dan ststusnya. Sunnah Nabi sebagai sumber ajaran Islam mengajarkan perdamaian, mengajak untuk menghapus konflik dalam berbagai bidang dan tingkatan, agar manusia hidup bahagia. Konflik memang potensi yang tidak bisa dihindarkan sejalan dengan sunnatullah manusia yang tercipta dalam perbedaan. Kadang konflik sebenarnya juga memiliki semangat untuk melakukan perubahan ke arah yang lebih baik, maka di sinilah perlu dilakukan manajemen konflik secara positif, antara lain melalui ajaran keagamaan. Dalam Islam sebagaimana diajarkan oleh Nabbi Muhammad, ternyata penyelesaian konflik secara damai sangat ditekankan, dengan media dan cara apapun, termasuk dengan menggunakan kearifan budaya lokal. Hal ini menunjukkan Islam sebagai aama langit yang tetap dan terus membumi dan berdialektika dengan nilai-nilai manusia. Oleh karena kearifan Lokal merupakan warisan masa lalu maka perlu dilakukan rekonstruksi agar tetap aktual di dunia moderen.

\footnotetext{
${ }^{30}$ Takdir Rahmadi, hlm. 90.

${ }^{31}$ Fachruddin, Kearifan Lokal Daerah Lampung, dalam Fachruddin Dani Blog, Minggu, 4 April 2010

${ }^{32}$ Fauzie Nurdin, Budaya Muakhi; dan Pembangunan Daerah Menuju Masyarakat Bermartabat (Yogyakarta: Gama Media, 2009) h. $89-92$
} 


\section{DAFTAR PUSTAKA}

Alamsyah. Otentsitas Piagam Madinah. Bandung: Penerbit Pustaka, 2008.

Ayatrohaedi, Kepribadian Budaya Bangsa (local Genius). Jakarta: Pustaka Jaya, 1986.

Azim, Mohammad Tahlil. Religiosity and Conflict Handling Styles: A Study of a Muslim Community, dalam International Journal of Islamic Thought, Vol. 12: (Dec.) 2017.

Basrin, Erwin. Profil Singkat Selepu Lebong, http://rejangkeme.blogspot.com

Cader, Akram Abdul, Islamic Principles of Conflict Management, dalam International Journal of Cross Culture pada Nopember 2017, h. 1-9.

Faizin, Muadil, "Piagam Madinah dan Resolusi Konflik di Indonesia, Jurnal Nizham, vol V, no. 01, edisi Januari - Juni 2017.

Gunaryo, Ahmad. Mediasi dan Resolusi Konflik di Indonesia, dari Konflik Agama Hingga Mediasi Peradilan, Semarang: WCM, 2007.

Harjuna, Muhammad, Resolusi Konflik dalam Islam, jurnal Religi, Vol. XIV, No. 1, Jan-Juni 2018, h. 23-43

Hasan, Ahmadi. Adat Badamai dalam Budaya Masyarakat Banjar. Banjarmasin: IAIN Antasari Press, 2009.

Ibn al-Qayyim al-Jauziyyah, I'lâm al-Muwaqqi'in 'an Rabb al-'Alamîn, Beirut: Dâr al-Fikr, 1995. Ibn Hisyam, al-Sîrah al-Nabawiyah, vol. I, al-Bâbi wa al-Halabi, Kairo, hlm. 150.

Ibn Ishak, Sîrah al-Rasûl, Beirut: Dâr al-Fikr,1970.

Karîm, Khalîl Abdul. al-Juzûrut Târikhiyah lis Syarîah Islâmiyah, terjemah oleh Kamran, , Yogyakarta: PT LKiS, 2010.

Liliweri, Alo. Prasangka dan Konflik, Komunikasi Lintas Budaya Masyarakat Multikultur. Yogyakarta: LKIS, 2009.

M. Watt, William. Muhammad at Madina, Oxford: Oxford University Press, 1956.

Nurdin, Fauzie. Budaya Muakhi; dan Pembangunan Daerah Menuju Masyarakat Bermartabat, Yogyakarta: Gama Media, 2009.

Rahmadi,Takdir. Mediasi; Penyelesaian Sengketa Melalui Pendekatan Mufakat, PT Raja Jakarta: Grafindo, 2010.

Soekanto, Soerjono, Sosiologi Sautu Pengantar, Jakarta : Rajawali Press, 1990.

Sriyanto, Agus. Penyelesaian Konflik Berbasis Budaya Lokal, dalam jurnal Ibda', $\mathrm{P}_{3} \mathrm{M}$ STAIN Purwokerto, Vol. 5, No. 2, Jul-Des 2007.

Susan, Novri, Sosiologi Konflik dan Isu-Isu Konflik Kontemporer, Jakarta: Kancana Media Group, 2009.

Wignjodipoero, Soerjono, Pengantar dan Asas-asas Hukum Adat. Jakarta: CV. Haji Masagung., 1967. 
98 | Asy-Syari'ah Vol. 22 No.1, Juni 2020 
Asy-Syari'ah (P-ISSN: 2086-9029 E-ISSN: 2654-5675) is a periodical scientific journal that publishes various results of studies and research, literature review, and other scientific works whose scope covers the field of Islamic law/sharia, law and society in monodisciplinary, interdisciplinary, and multidisciplinary manners. The journal aims to expand and create innovative concepts, theories, paradigms, perspectives and methodologies in the above said scope. The Journal is published twice a year (june and december) by Faculty of Shariah and Law, Sunan Gunung Djati State Islamic University Bandung in collaboration with Asosiasi Sarjana Syariah Indonesia (ASSYI).

\section{EDITORIAL OFFICE:}

Fakultas Syariah dan Hukum UIN Sunan Gunung Djati Bandung J1. Raya A.H. Nasution No. 105 Cibiru Kota Bandung, 40614

Tlp/Fax: +022-7802278 Faks. 022-7802278

Website http://journal.uinsgd.ac.id/index.php/asy-syariah/index

E-mail: Jurnalasy-syariah@uinsgd.ac.id 